\title{
Vertical Distribution of Ozone and Nitric Acid Vapor on the Mammoth Mountain, Eastern Sierra Nevada, California
}

Andrzej Bytnerowicz ${ }^{1}$, David R. Parker ${ }^{2}$, and Pamela E. Padgett ${ }^{1}$

${ }^{1}$ USDA Forest Service, Pacific Southwest Research Station, 4955 Canyon Crest Drive, Riverside, CA 92507, ${ }^{2}$ Department of Environmental Sciences, University of California, Riverside, CA 92521

Received September 4, 2001; Revised October 29, 2001; Accepted November 14, 2001; Published January 5, 2002

In August and September 1999 and 2000, concentrations of ozone $\left(\mathrm{O}_{3}\right)$ and nitric acid vapor $\left(\mathrm{HNO}_{3}\right)$ were monitored at an elevation gradient $(2184-3325 \mathrm{~m})$ on the Mammoth Mountain, eastern Sierra Nevada, California. Passive samplers were used for monitoring exposure to tropospheric $\mathrm{O}_{3}$ and $\mathrm{HNO}_{3}$ vapor. The 2-week average $\mathrm{O}_{3}$ concentrations ranged between 45 and $72 \mathrm{ppb}$, while $\mathrm{HNO}_{3}$ concentrations ranged between 0.06 and $0.52 \mu \mathrm{g} / \mathrm{m}^{3}$. Similar ranges of $\mathrm{O}_{3}$ and $\mathrm{HNO}_{3}$ were determined for 2 years of the study. No clear effects of elevation on concentrations of the two pollutants were detected. Concentrations of $\mathrm{HNO}_{3}$ were low and at the background levels expected for the eastern Sierra Nevada, while the measured concentrations of $\mathrm{O}_{3}$ were elevated. High concentrations of ozone in the study area were confirmed with an active UV absorption $\mathrm{O}_{3}$ monitor placed at the Mammoth Mountain Peak (September 5-14, 2000, average 24-h concentration of $56 \mathrm{ppb}$ ).

KEY WORDS: ozone, nitric acid vapor, elevation change, passive sampling, active monitoring

DOMAINS: plant sciences, global systems; environmental management and policy, ecosystems management, environmental monitoring

\section{INTRODUCTION}

Ambient tropospheric ozone $\left(\mathrm{O}_{3}\right)$ results from production in the free troposphere, injection from the stratosphere to the troposphere, photochemical production, photolysis, dry deposition, and chemical destruction[1]. Stomatal uptake of vegetation, especially by forest canopies, may significantly affect ambient $\mathrm{O}_{3}$ concentrations[2]. First measurements of tropospheric $\mathrm{O}_{3}$ concentrations made between 1876 and 1910 at Montsouris near Paris showed background levels of $\sim 10 \mathrm{ppb}[3]$. Concentrations of $\mathrm{O}_{3}$ increase gradually in the Northern Hemisphere - over the last 30 years, 1-2\% annual increase of $\mathrm{O}_{3}$ concentrations has been recorded in Europe[4]. At present, $\mathrm{O}_{3}$ concentrations of $>50-60 \mathrm{ppb}$ are often measured as the background levels[5]. $\mathrm{O}_{3}$ is a criteria pollutant affecting human health at elevated concentrations[6]. It has been well 
established that $\mathrm{O}_{3}$ may be toxic to vegetation at concentrations $>30-40 \mathrm{ppb}$ and that severity of plant damage depends on a length and characteristics of the exposure and various abiotic and biotic factors[7,8,9].

In dense urban areas such as southern California, nitrogen oxides are a major component of photochemical smog. During the photochemical smog formation process, nitric oxide (NO) is rapidly oxidized to nitrogen dioxide $\left(\mathrm{NO}_{2}\right)$ that subsequently reacts with hydroxyl radicals producing nitric acid $\left(\mathrm{HNO}_{3}\right)$ vapor[10,11]. While $\mathrm{NO}_{2}$ is often the dominant nitrogenous $(\mathrm{N})$ pollutant[12,13], $\mathrm{HNO}_{3}$ vapor may be more relevant to problems associated with $\mathrm{N}$ deposition to forests and other ecosystems because of its unusually high deposition velocity[14,15]. In areas of high ambient concentrations, $\mathrm{HNO}_{3}$ may also exhibit direct toxic effects on foliage of forest vegetation[16].

Concentrations of $\mathrm{O}_{3}$ and $\mathrm{HNO}_{3}$ vapor in areas affected by photochemical smog are strongly correlated in several locations in the Los Angeles Basin[17]. However, in mountain locations down-wind from the photochemical source areas, concentrations of $\mathrm{HNO}_{3}$ decrease more rapidly than those of $\mathrm{O}_{3}$ due to high deposition velocity of $\mathrm{HNO}_{3}$ vapor[18].

There is a rapidly growing interest in passive sampling systems for quantifying exposure to ambient concentrations of gaseous air pollutants. Excluding the laboratory analysis costs, passive samplers are inexpensive, easy to use, and do not require electricity to operate. Therefore, they are very attractive for use in remote and wilderness areas and for regional scale air-quality assessments[19]. Application of passive samplers has allowed acquisition of important information on spatial and temporal distribution of $\mathrm{O}_{3}$ exposure for the entire Sierra Nevada range[20,21] and $\mathrm{O}_{3}, \mathrm{NH}_{3}, \mathrm{NO}_{2}$, and $\mathrm{HNO}_{3}$ in Sequoia National Park[22].

Sierra Nevada Mountains are the primary topographic feature of the state of California. These mountains have tremendous ecological, economical, and recreational values[23]. Sierra Nevada is quite diversified in regard to air pollution distribution. Western slopes of the Sierra Nevada are strongly affected by pollution generated in the San Francisco Bay and Central Valley[24], while the eastern Sierra Nevada has been regarded as a clean area with relatively low pollutant concentrations[25,26,27]. The Mammoth Mountain near Mammoth Lakes in Eastern Sierra Nevada (Fig. 1) is a popular recreational location for millions of Californians, as well as visitors from other states and abroad.

\section{METHODOLOGY}

Air pollution monitoring on the Mammoth Mountain was performed during the summer class "Acquisition and Analysis of Environmental Data," organized by the Department of Environmental Sciences of the University of California in Riverside. The $\mathrm{O}_{3}$ passive samplers[28] produced by Ogawa \& Co., USA, Inc., and $\mathrm{HNO}_{3}$ samplers[30] were used. The samplers were exposed from August 20 to September 7, 1999, and from August 21 to September 6, 2000, at locations presented in Fig. 2 and described in Table 1. Passive samplers were placed about $2 \mathrm{~m}$ above the ground on PVC poles - each sampler contained two replicate filters subsequently used for analyses. Nitrate from the $\mathrm{O}_{3}$ samplers' filters, a product of nitrite oxidation by $\mathrm{O}_{3}$, was extracted with nanopure water and determined with ion chromatography (Dionex 4000i)[28,29]. Nitrate from nylon filters, a product of $\mathrm{HNO}_{3}$ absorption, was also extracted with nanopure water, and its concentrations were determined colorimetrically (TRAACS 2000 Bran \& Lueble Instrument)[30,31]. $\mathrm{O}_{3}$ passive samplers were calibrated against a UV-absorption instrument (Thermo Environmental Model 49) located nearby in Yosemite National Park. $\mathrm{HNO}_{3}$ samplers were calibrated against honeycomb denuder systems in continuously stirred tank reactor (CSTR) chambers located at the University of California in Riverside[32]. Between September 5 and 14, 2000, concentration of $\mathrm{O}_{3}$ at the Mammoth Mountain Peak were also measured with a 2B Technologies UV-absorption instrument[33]. 


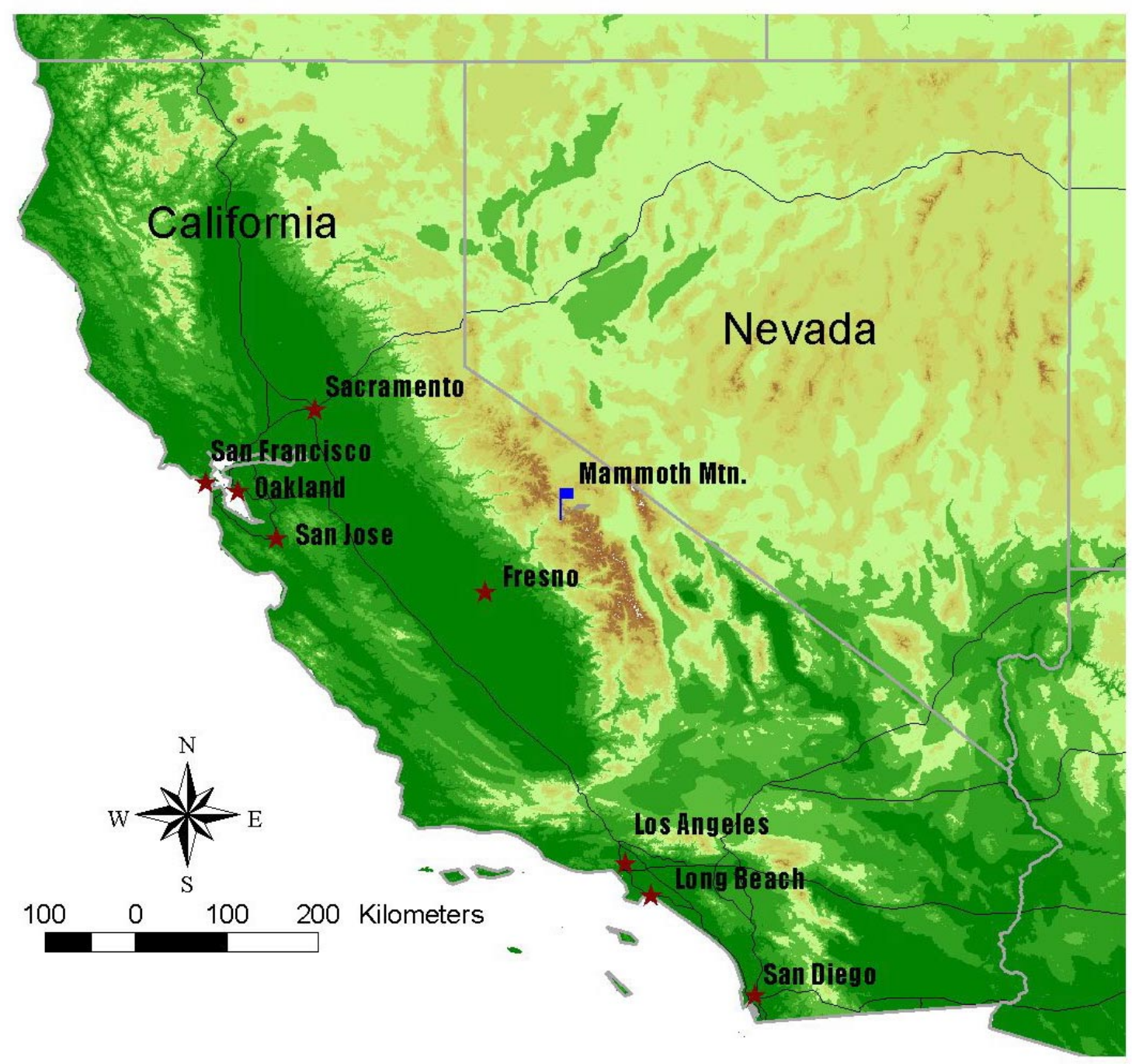

FIGURE 1. Location of Mammoth Mountain in Sierra Nevada, California.

TABLE 1

\section{Location and Elevation of Monitoring Sites on Mammoth Mountain}

Site Number

1

2

3

4

5

$5 B$

6

\section{Name}

Name
Rainbow Falls
Starkweather Lake
Agnew Meadows
Minaret Summit
Chair 14
Deadman's Pass
Mammoth Mountain Summit

Elevation (m) 1999 2000 $2267 \quad 2184$

$2416 \quad 2416$

$2591 \quad 2688$

$2810 \quad 2810$

$3152 \quad 3152$

- 3135

$3350 \quad 3325$ 


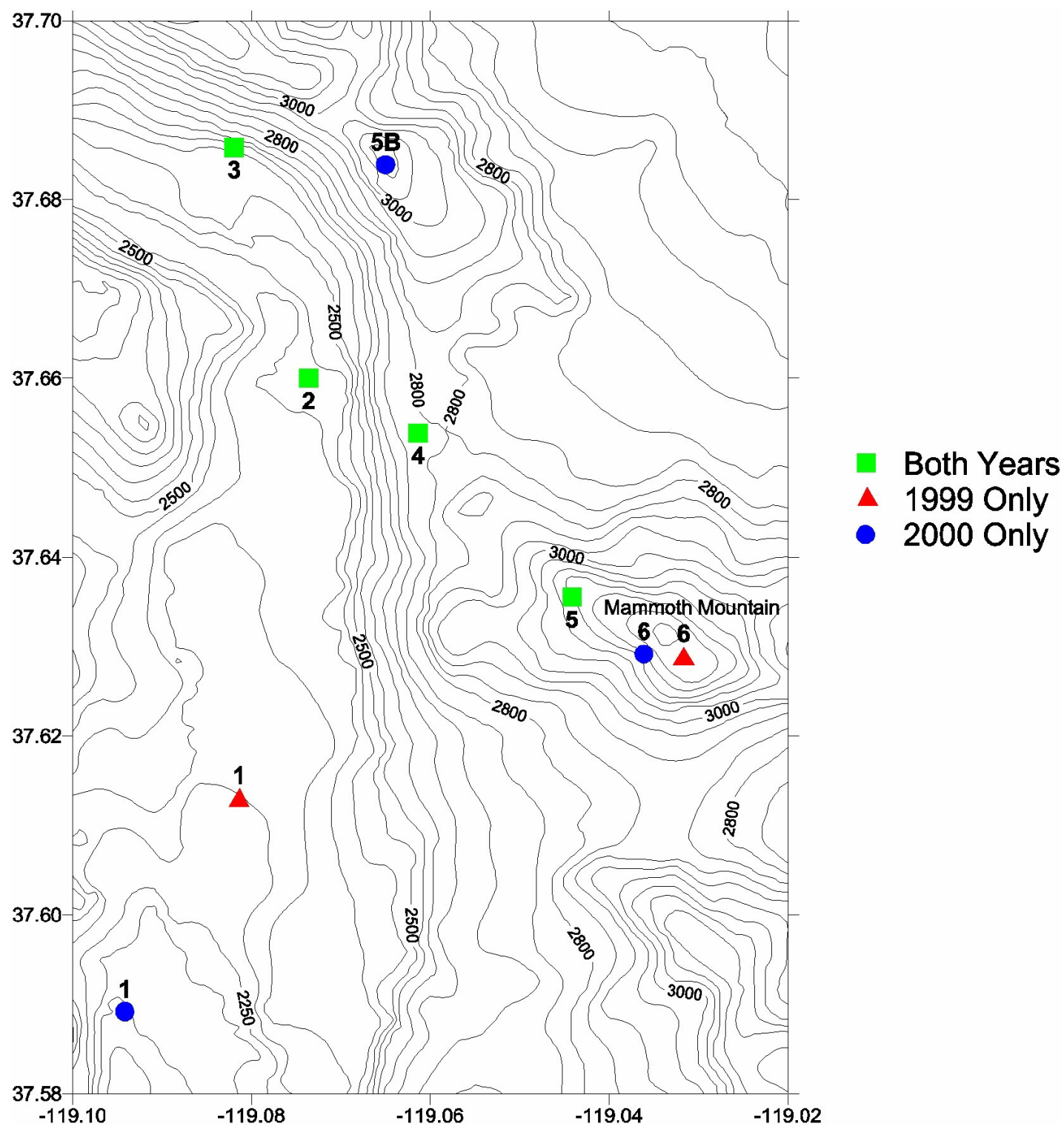

FIGURE 2. Location of monitoring sites on Mammoth Mountain.

\section{RESULTS AND DISCUSSION}

\section{Ozone}

Concentrations of $\mathrm{O}_{3}$ in 1999 increased with elevation up to $2810 \mathrm{~m}$ (Minaret Summit site), decreased at $3152 \mathrm{~m}$ (Chair 14), and increased to the highest level of $72 \mathrm{ppb}$ at $3330 \mathrm{~m}$ (Mammoth Mountain Peak). In 2000 no clear effect of elevation on $\mathrm{O}_{3}$ concentrations was recorded. $\mathrm{O}_{3}$ concentrations at the 2416-, 2688-, 2810-, and 3152-m sites (Starkweather Lake, Agnew Meadows, Minaret Summit and Chair 14, respectively) were similar to the 1999 values. However, when in 2000 the Rainbow Falls site was moved to the more exposed but lower elevation location, the $\mathrm{O}_{3}$ concentrations significantly increased. On the other hand, when location of the passive sampler on the Mammoth Mountain Peak was moved $25 \mathrm{~m}$ lower, the $\mathrm{O}_{3}$ concentrations decreased (Fig. 3). 


\section{Ozone concentrations vs. elevation change}

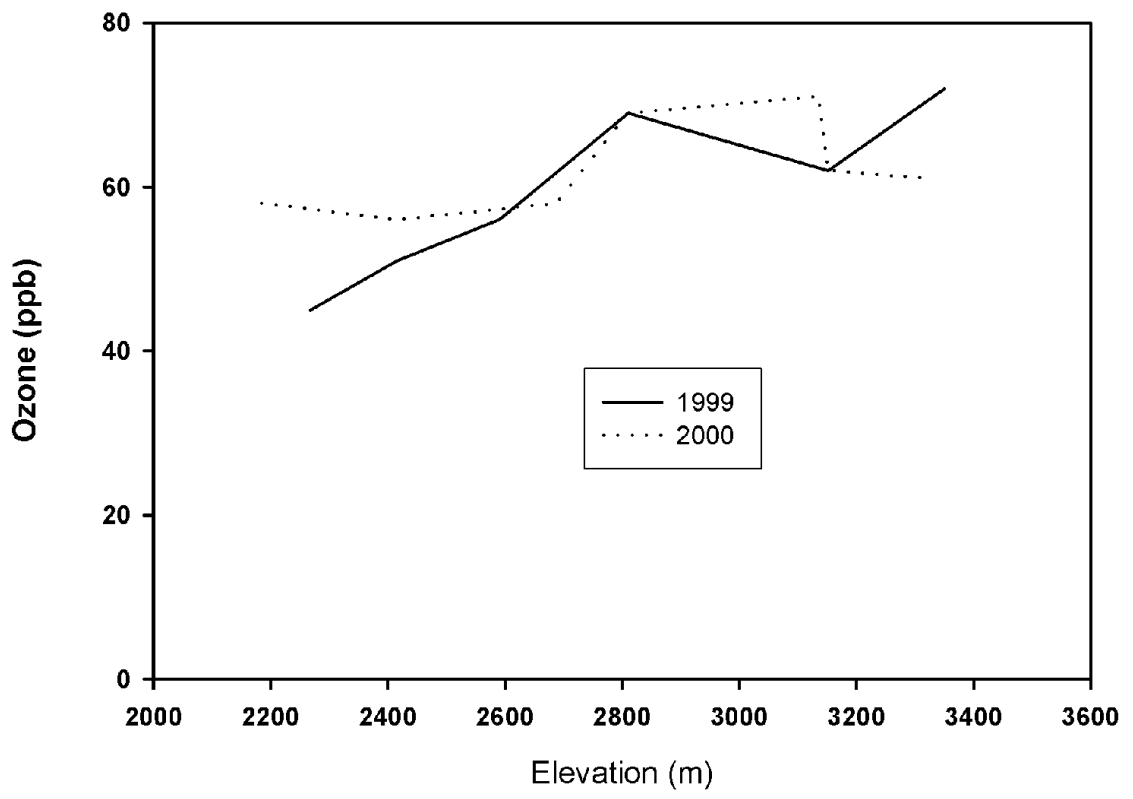

FIGURE 3. Concentrations of $\mathrm{O}_{3}$ determined with passive samplers on Mammoth Mountain.

Measurements of $\mathrm{O}_{3}$ concentrations with an active monitor at the Mammoth Mountain Peak confirmed high levels of the pollutant determined with passive samplers near that site during 1999 and 2000 measurements. Diurnal distribution of $\mathrm{O}_{3}$ concentrations varied between individual days without any particular pattern. Examples of diurnal distribution for 4 days are presented on Fig. 4. The lowest recorded value was $35 \mathrm{ppb}$ on September 12, while during other days $\mathrm{O}_{3}$ levels stayed $>40 \mathrm{ppb}$. On September 8 the $\mathrm{O}_{3}$ levels reached $73 \mathrm{ppb} . \mathrm{O}_{3}$ average concentration for the entire period of active monitoring was $56 \mathrm{ppb}$ (S.D. $10 \mathrm{ppb}$ ). These values are similar to those recorded in August 1987 at the nearby Eastern Brook Lake in the eastern Sierra Nevada[34]. These concentrations can be considered as elevated above normal background concentrations for the Sierra Nevada - in other parts of the Sierra Nevada range, far from the photochemical smog source areas, 2-week average $\mathrm{O}_{3}$ concentrations stayed $\sim 40 \mathrm{ppb}[35,36]$. Persistence of high $\mathrm{O}_{3}$ levels and a lack of clear diurnal patterns indicated that the pollutant originated in a remote pollution source area, either in California Central Valley or southern California. Transport of polluted air masses from southern California through the Tehachapi and Cajon Passes takes place[37], therefore increased levels of the pollutant along the eastern Sierra Nevada should be considered. If these were true, the expected concentrations of $\mathrm{O}_{3}$ at sites located more to the south and closer to the source area would be higher. However, results of recent air-quality measurements indicate that concentrations of $\mathrm{O}_{3}$ in the Bishop area (maximum 8 -h average concentrations $\sim 60 \mathrm{ppb}$ ) are much lower than at Mammoth Lakes located about 70 $\mathrm{km}$ to the north (maximum 8-h average concentrations $\sim 100 \mathrm{ppb}$ )[38]. Therefore, a possibility of transport of the polluted air masses from California Central Valley across the Sierra Nevada seems to be more plausible. We suggest that polluted air masses from the Fresno area in the San Joaquin Valley (maximum 8-h $\mathrm{O}_{3}$ average concentrations approaching $126 \mathrm{ppb}$ ) may be transported with prevailing summer winds[39] along the San Joaquin River drainage into the Mammoth Mountain area). 


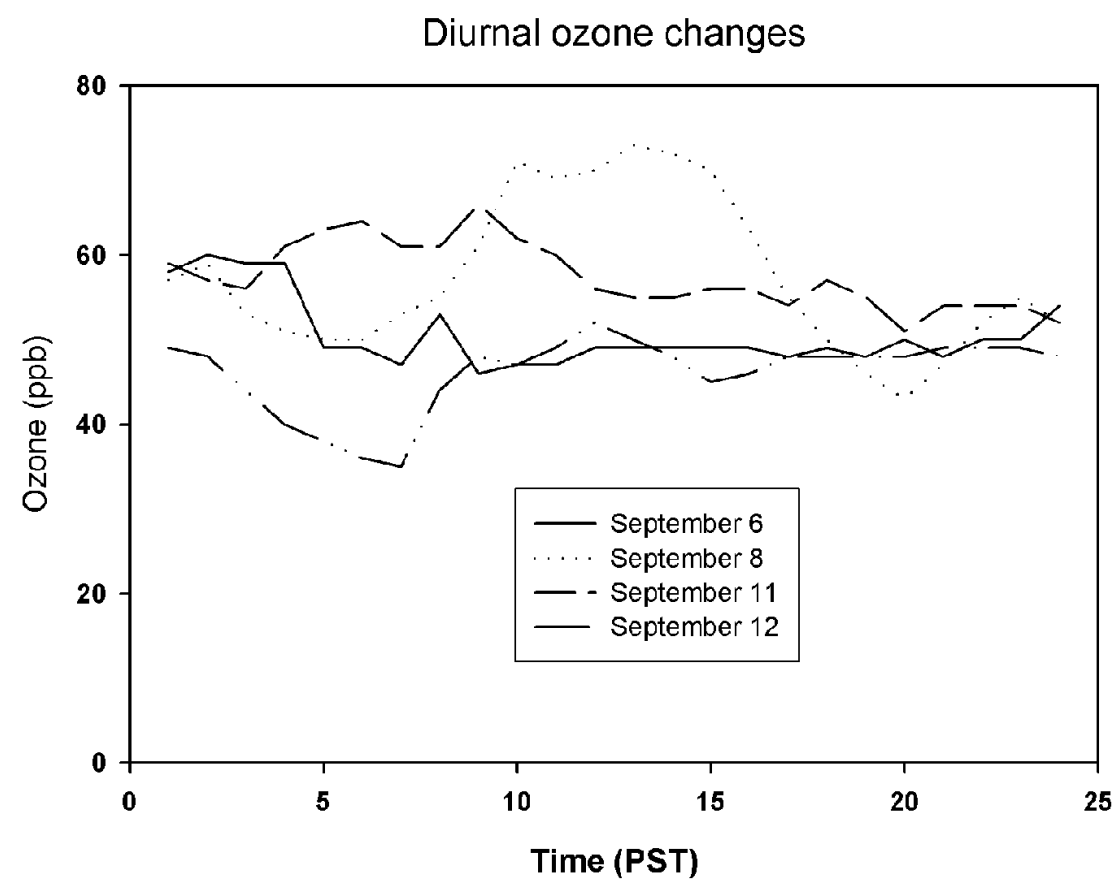

FIGURE 4. Concentrations of $\mathrm{O}_{3}$ determined with an active UV absorption monitor at the Mammoth Mountain Peak.

\section{Nitric Acid Vapor}

During the 1999 study $\mathrm{HNO}_{3}$ concentrations increased with elevation with an exception of Agnew Meadows $(2591 \mathrm{~m})$ that was as low as the lowest-elevation Rainbow Falls site $(2267 \mathrm{~m})$. In 1999 the $\mathrm{HNO}_{3}$ concentrations ranged between 0.06 and $0.52 \mu \mathrm{g} / \mathrm{m}^{3}$. During the 2000 study no clear relationship with elevation was detected, but ranges of concentrations remained within those seen in $1999\left(0.25-0.42 \mu \mathrm{g} / \mathrm{m}^{3}\right)$. In general, the detected $\mathrm{HNO}_{3}$ concentrations were at low background levels and similar to $0.36 \mu \mathrm{g} / \mathrm{m}^{3}$ summer average detected in the nearby Eastern Brook Lakes[27]. These results are also similar to other remote mountain locations in North America[40]. In the western Sierra Nevada $\mathrm{HNO}_{3}$ levels are higher - at Whitaker Forest the 24$\mathrm{h}$ average daytime $\mathrm{HNO}_{3}$ concentration in summer of 1990 was $\sim 1.1 \mu \mathrm{g} \mathrm{m}{ }^{-3}$ [41]. At high elevation locations in Sequoia National Park, 2-week long average $\mathrm{HNO}_{3}$ concentrations ranged between 0.04 and $1.4 \mu \mathrm{g} / \mathrm{m}^{3}$ in summer 1999[42]. In the moderately polluted Barton Flat site of the San Bernardino Mountains, the average 24-h concentrations $\mathrm{HNO}_{3}$ ranged from 3.0 to $6.5 \mu \mathrm{g}$ $\mathrm{m}^{-3}$ during the 1993-1995 summer seasons[16]. Although we assume that polluted air from the San Joaquin Valley contained high concentrations of $\mathrm{O}_{3}$, concentrations of $\mathrm{HNO}_{3}$ were drastically depleted compared to the source area due to a very high reactivity of the pollutant[14] and deposition to rocks and vegetation before reaching the receptor area. At the $\mathrm{HNO}_{3}$ levels recorded at the Mammoth Mountain, no phytotoxic effects or significant levels of nitrogen deposition to natural ecosystems can be expected[43].

This study indicated that application of relatively simple techniques such as passive sampling offers new opportunities for evaluation of air quality in remote locations. Such information is urgently needed, especially for land managers of ecologically important areas. The Mammoth Mountain is in close vicinity of the John Muir and Ansel Adams Wilderness areas. These important Class I areas require special federal protection and should have good air quality for protection of sensitive flora and fauna and for well-being of numerous local inhabitants and visitors coming for recreation and rest. 


\section{Nitric acid concentrations vs. elevation change}

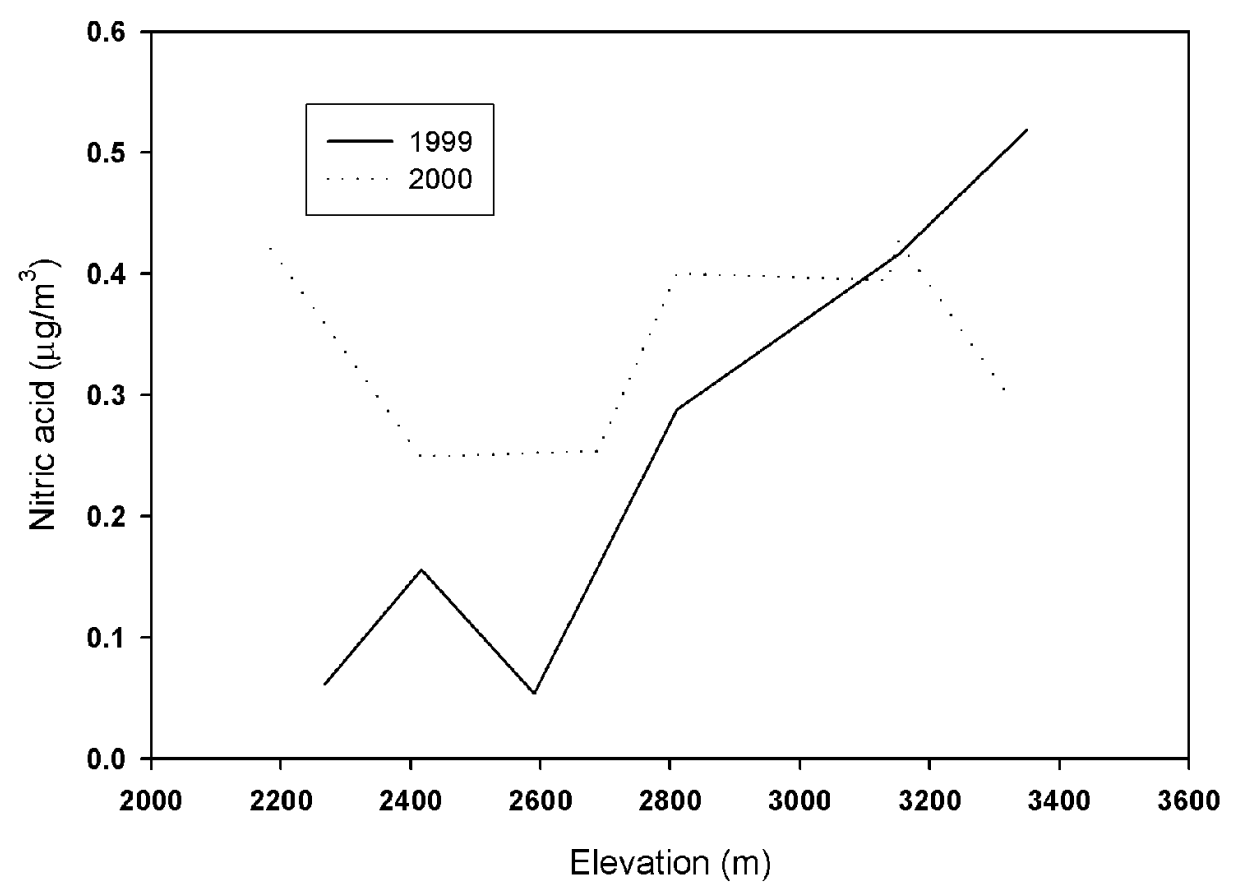

FIGURE 5. Concentrations of $\mathrm{HNO}_{3}$ determined with passive samplers on the Mammoth Mountain.

\section{CONCLUSION}

The Mammoth Mountain in the eastern Sierra Nevada is exposed to $\mathrm{O}_{3}$ concentrations that are elevated above background. This was not expected in this location, which is distant and separated from the photochemical smog source areas by the Sierra Nevada range. A possibility of a transSierra Nevada transport of polluted air masses from the polluted San Joaquin Valley is high.

$\mathrm{HNO}_{3}$ vapor concentrations, however, were low and at the expected background levels may not pose a threat to natural resources or to humans of the investigated area.

This study showed that passive samplers are very useful for monitoring of air pollutants in remote mountain locations. Such samplers can also serve as simple educational tools for students interested in environmental pollution problems.

\section{ACKNOWLEDGMENTS}

We thank students of the UC Riverside ES 176 class for participation in data collection. We also thank Ed Betty of the University of California in Riverside, Environmental Sciences Department, and Diane Alexander of the USDA Forest Service Pacific Southwest Research Station in Riverside, CA, for chemical analyses of the collected samples, as well as Susan Schilling of the USDA Forest Service Pacific Southwest Research Station for help in preparation of graphics. Fig. 1 was produced based on data distributed by EROS Data Center Distributed Active Archive Center (EDC DAAC), located at the U.S. Geological Survey's EROS Data Center in Sioux Falls, SD. 


\section{REFERENCES}

1. Altshuler, A.P. (1986) The role of nitrogen oxides in nonurban ozone formation in the planetary boundary layer over N. America, W. Europe and adjacent area of ocean. Atmos. Environ. 20, 245-268.

2. Miller, P.R. (1992) Mixed conifer forests of the San Bernardino Mountains. In The Response of Western Forests to Air Pollution. Olson, R.K., Binkley, D., and Bohm, M., Eds. Ecological Studies 97. SpringerVerlag, New York. pp. 461-497.

3. Seinfeld, J.H. and Pandis, S.N. (1998) Atmospheric Chemistry and Physics. John Wiley \& Sons, New York, $1326 \mathrm{p}$.

4. Janach, W.E. (1989) Surface ozone: trend details, seasonal variations, and interpretation. J. Geophys. Res. 94, $18289-18295$.

5. Lefohn, A.S., Oltmans, S.J., Dann, T., and Singh, H.W. (2001) Present-day variability of background ozone in lower troposphere. J. Geophys. Res. 106, 9945-9958.

6. Environmental Protection Agency. (1996) Air Quality Criteria for Ozone and Related Photochemical Oxidants. Washington, D.C.

7. Krupa, S.V. and Manning, W.J. (1988) Atmospheric ozone: formation and effects on vegetation. Environ. Pollut. 50, 101-137.

8. Legge, A.H., , Grünhage, L., Nosal, M., Jäger, H.J., and Krupa, S.V. (1995) Ambient ozone and adverse crop response: an evaluation on north American and European data as they relate to exposure indices and critical levels. Angew. Bot. 69, 192-205.

9. Skärby, L. and Karlsson, P.E. (1996) Critical levels for ozone to protect forest trees - best available knowledge from the Nordic countries and the rest of Europe. In Critical Levels for Ozone in Europe: Testing and Finalizing the Concepts. Kärenlampi, L. and Skärby, L., Eds. UN-ECE Workshop Report. University of Kuopio, Finland. pp. 72-85.

10. Crutzen, P.J. (1979) The role of $\mathrm{NO}$ and $\mathrm{NO}_{2}$ in chemistry of the troposphere and the stratosphere. Ann. Rev. Earth Planet Sci. 7, 443-472.

11. Finlayson-Pitts, B. and Pitts, J.N., Jr. (1986) Atmospheric Chemistry: Fundamentals and Experimental Techniques. John Wiley \& Sons, New York.

12. Ollinger, S.V., Aber, J.D., Lovett, G.M., Millham, S.E., Lathrop, R.G., and Ellis, J.M.(1993) A spatial model of atmospheric deposition for the northeastern US. Ecol. Appl. 3, 459-472.

13. Bytnerowicz, A. and Fenn, M.E. (1996) Nitrogen deposition in California: a review. Environ. Pollut. 92 , 127-146.

14. Hanson. P.J. and Lindberg, S.E. (1991) Dry deposition of reactive nitrogen compounds: a review of leaf, canopy, and non-foliar measurements. Atmos. Environ. 25A, 1615-1634.

15. Lovett, G.M. (1994) Atmospheric deposition of nutrients and pollutants in North America: an ecological perspective. Ecol. Appl. 4, 629-650.

16. Bytnerowicz, A., Padgett, P., Percy, K., Krywult, M., Riechers, G., and Hom, J. (1999) Direct effects of nitric acid on forest trees. In Oxidant Air Pollution Impacts in the Montane Forests of Southern California. Miller, P.R. and McBride, J.R., Eds. Ecological Series 134. Springer-Verlag, New York. pp. 270-287.

17. Cal Tech EQL. (1986) Acquisition of Acid Vapor and Aerosol Concentration Data for Use in Dry Deposition Studies in the South Coast Air Basin. EQL Report 25. Environmental Quality Laboratory, California Institute of Technology. Pasadena, CA.

18. Bytnerowicz, A., Fenn, M.E., Miller, P.R., and Arbaugh, M.J. (1999) Wet and dry pollutant deposition to the mixed conifer forest. In Oxidant Air Pollution Impacts in the Montane Forests of Southern California. Miller, P.R. and McBride, J.R., Eds. Ecological Series 134. Springer-Verlag, New York. pp. 235-269.

19. Krupa, S.V. and Legge, A.H. (2000) Passive sampling of ambient gaseous air pollutants: an assessment from an ecological perspective. Environ. Pollut. 107, 31-45.

20. Praisler, H.K., Arbaugh, M.J., Bytnerowicz, A., and Schilling, S.L. (2001) A statistical model for estimating spatial and temporal ambient ozone patterns in the Sierra Nevada, California. TheScientificWorld, submitted.

21. Fraczek, W., Bytnerowicz, A., and Arbaugh, M. (2001) Application of the ESRI Geostatistical Analysts for development of ozone distribution models in the Carpathian and Sierra Nevada Mountains. TheScientificWorld, in press.

22. Bytnerowicz, A., Tausz, M., Alonso, R., Jones, D., Johnson, D., and Grulke, N.(2002) Summer-time distribution of air pollutants in Sequoia National Park, California. Environ. Pollut., in press.

23. Schoenherr, A.A. (1995) A Natural History of California. University of California Press, Berkeley, $772 \mathrm{p}$.

24. Van Ooy, D.J. and Carroll, J.J. (1995) The spatial variation of ozone climatology on the western slope of the Sierra Nevada. Atmos. Environ. 29, 1319-1330.

25. Miller, D.F. and Walsh, P.A. (1991) Air Quality and Acid Deposition in the Southeastern Sierra Nevada. Paper presented at the $84^{\text {th }}$ Annual Meeting and Exhibition of the Air and Waste Management Association, Vancouver, June. 
26. Bytnerowicz, A., Dawson, P.J., Morrison, C.L., and Poe, M.P. (1991) Deposition of atmospheric ions to pine branches and surrogate surfaces in the vicinity of Emerald Lake watershed, Sequoia National Park. Atmos. Environ. 25A, 2203-2210.

27. Bytnerowicz, A., Dawson, P.J., Morrison, C.L., and Poe, M.P. (1992) Atmospheric dry deposition on pines in the Eastern Brook Lake watershed, Sierra Nevada, California. Atmos. Environ. 26A, 3195-3201.

28. Koutrakis, P., Wolfson, J.M., Bunyaviroch, A., Froelich, S.E., Hirano, K., and Mulik, J.D. (1993) Measurement of ambient ozone using a nitrite-saturated filter. Anal. Chem. 65, 210-214.

29. Dionex 4000i. (2001) Manual and Literature July 2001, Dionex Corporation, Sunnyvale, CA.

30. Bytnerowicz, A., Padgett, P., Arbaugh, M., Parker, D., and Jones, D. (2001) Passive sampler for measurements of nitric acid vapor $\left(\mathrm{HNO}_{3}\right)$ concentrations. TheScientificWorld, in press.

31. Technicon Industrial Systems Corporation (1987) Bran and Lueble Industrial Method No. 818-87T, Tarrytown, NY.

32. Koutrakis, P., Sioutas, C., Ferguson, S.T., Wolfson, J.M., Mulik, J.D., and Burton, R.M. (1993) Development and evaluation of a glass honeycomb denuder/filter pack system to collect atmospheric gases and particles. Environ. Sci. Technol. 27, 2497-2501.

33. Bognar, J.A. and Birks, J.W. (1996). Miniaturized ultraviolet ozonesonde for atmospheric measurements. Anal. Chem. 68, 3059-3062.

34. Miller, D.F. and Walsch, P.A. (1991) Air quality and acid deposition in the southeastern Sierra Nevada. Presented at the $84^{\text {th }}$ Annual Meeting and Exhibition of the Air and Waste Management Association, Vancouver, June. $22 \mathrm{p}$.

35. Bytnerowicz, A., Carroll, J.J., Takemoto, B.K., Miller, P.R., Fenn, M.E., and Musselman, R.C. (2000) Distribution and transport of air pollutants to vulnerable California ecosystems. In Integrated Assessment of Ecosystem Health. Scow, K.M. Fogg, G.E., Hinton, D.E., and Johnson, M.L. Eds. Lewis Publishers, Boca Raton, FL. pp. 93-118.

36. Carroll, J. (2001) University of California, Davis, personal communication.

37. McElroy, J.L. (1987) Estimation of pollutant transport and concentration distribution overt complex terrain of southern California using airborne lidar. J. Air Pollut. Contr. Assoc. 37, 1046-1051.

38. California Air Resources Board. (1999) Ozone Data Summary 1995-1998, http://arbis.arb.ca.gov/aqd/ozone/

39. California Air Resources Board. (1984) California Surface Wind Climatology. State of California, California Air Resources Board, Aerometric Data Division.

40. Legge, A.H. and Krupa, S.V. (1989) Air quality at a high elevation, remote site in western Canada. Paper presented at the $82^{\text {nd }}$ Annual Meeting and Exhibition of the Air and Waste Management Association, Anaheim, California, June.

41. Bytnerowicz, A. and Riechers, G. (1995) Nitrogenous air pollutants in a mixed conifer stand of the western Sierra Nevada, California. Atmos. Environ. 29, 1369-1377.

42. Bytnerowicz, A., Tausz, M., Alonso, R., Jones, D., Johnson, R., and Grulke, N. (2002) Summer time distribution of air pollutants in Sequoia National Park, California. Environ. Pollut., in press.

43. Bytnerowicz, A., Dueck, T., and Godzik, S. (1998) Nitrogen oxides, nitric acid vapor, and ammonia. In Recognition of Air Pollution Injury to Vegetation: A Pictorial Atlas. Flagler, R.B., Ed. Air and Waste Management Association, Pittsburgh, PA. 5-1 through 5-17.

\section{This article should be referenced as follows:}

Byternowicz, A., Parker, D.R., and Padgett, P.E. (2002) Vertical distribution of ozone and nitric acid vapor on the Mammoth Mountain, Eastern Sierra Nevada, California. In Proceedings of the International Symposium on Passive Sampling of Gaseous Air Pollutants in Ecological Effects Research. TheScientificWorldJOURNAL 2, 1-9. 

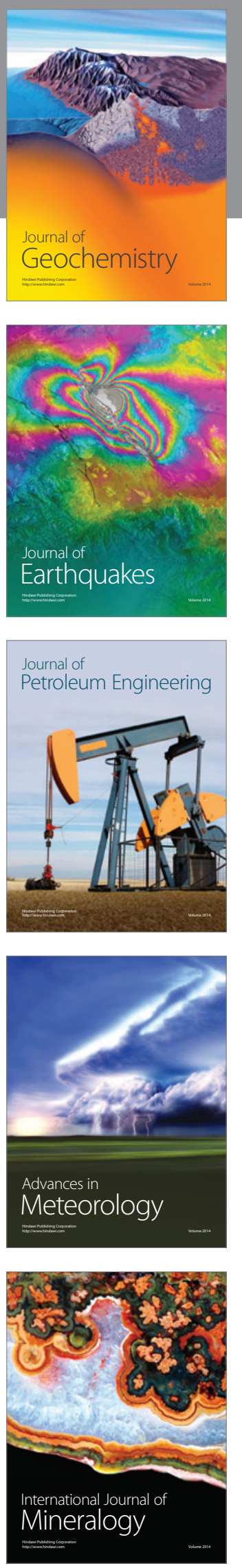
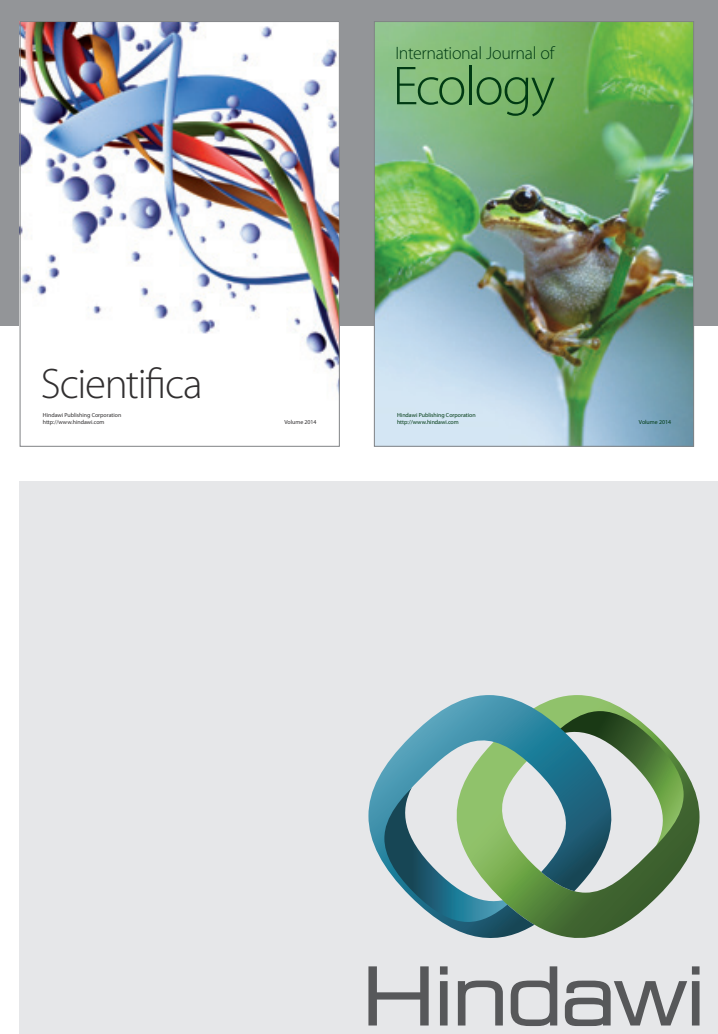

Submit your manuscripts at http://www.hindawi.com
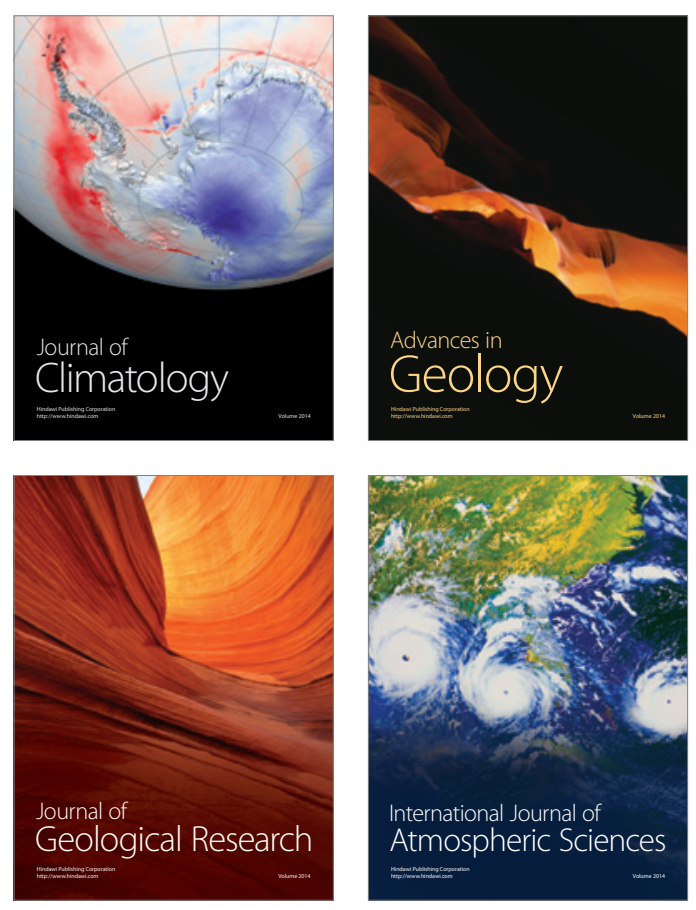
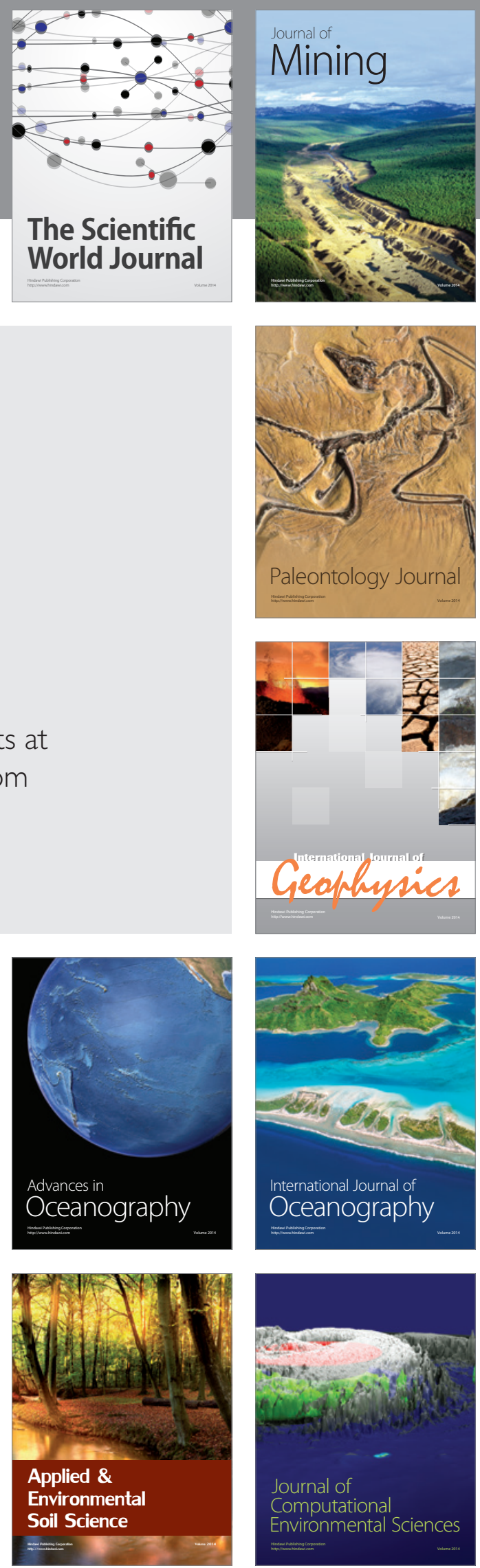